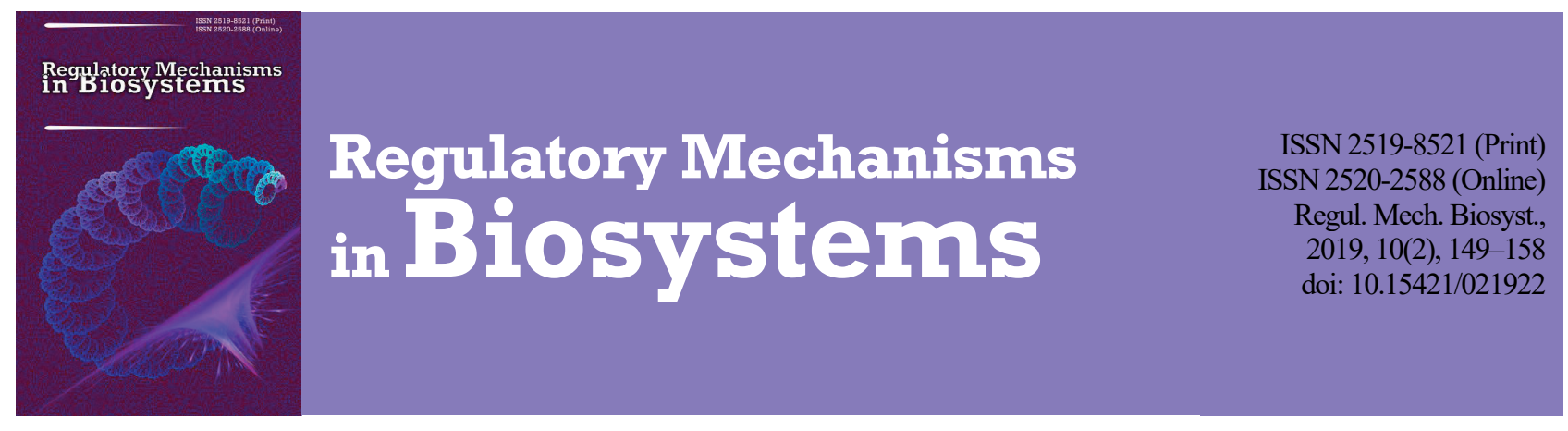

\title{
Metabolic processes in the organism of animals under the action of plant extract
}

\author{
O. Buchko*, V. Havryliak**, O. Yaremkevych**, R. Konechna**, N. Ohorodnyk*** \\ *Institute of Animal Biology, National Academy of Sciences of Ukraine, Lviv, Ukraine \\ **Lviv Polytechnic National University, Lviv, Ukraine \\ ***Lviv National Agrarian University, Dublany, Ukraine
}

Article info

Received 29.03.2019

Received in revised form 18.05 .2019

Accepted 19.05.2019

Institute of Animal Biology, NASU,

V. Stus st., 38, Lviv, 79034, Ukraine.

Tel.: +38-032-260-07-95.

E-mail:buchko_oksana@ukr.net

Lviv Polytechnic National

University, Stepan Bandery st., 12

Lviv, 79000, Ukraine.

Tel.: +38-032-258-21-11.

E-mail:havvita@ukr.net

Lviv National Agrarian University,

V. Velykyist., 1 ,

Dublany, 80381, Ukraine

Tel.: +38-032-224-24-98.

E-mail:nataohorodnyk@ukr.net

Buchko, O., Havryliak, V., Yaremkevych, O., Konechna, R., \& Ohorodnyk, N. (2019). Metabolic processes in the organism of animals under the action of plant extract. Regulatory Mechanisms in Biosystems, 10(2), 149-158. doi:10.15421/021922

The possibility of increasing metabolism and resistance in an organism of animals under the influence of biologically active substances of natural origin is considered in the paper. In the current study, we investigated the effect of $40 \%$ ethanolic extract of common nettle (Urtica dioica L.) on hematologic indexes (hemoglobin concentration, erythrocytes and leukocytes content), protein metabolism (total protein, aspartate aminotransferase (AST), alanine aminotransferase activities (ALT)), glutathione metabolism (peroxidase (GP), glutathione reductase (GR) and reduced glutathione content (GSH)), antioxidant defense systems (superoxide dismutase (SOD), catalase (CAT)), and indicators of free radical processes (lipid hydroperoxidation products (LHP), TBA-active products and carbonyl groups of protein (CP)) in the blood and tissues of normal and adrenalinstressed rats. White Wistar rats (male) with body weight 180-200 g were used in the experiments. The animals were divided into 4 groups (control and 3 experimental), each containing 7 animals. The animals of experimental groups $D_{2}$ and $D_{3}$ received $40 \%$ ethanolic extract of common nettle in a dose of $5 \mathrm{~mL} / \mathrm{kg}$ of body weight during 4 weeks. After 29 days of the experiment, the animals of $\mathrm{D}_{1}$ and $\mathrm{D}_{3}$ groups were intramuscularly administered $0.1 \%$ solution of adrenaline hydrochloride at a dose of $1 \mathrm{mg} / \mathrm{kg}$ of body weight. One day after the administration of adrenaline, the animals were decapitated under ether anesthesia. The objects of the study were blood and homogenates of liver, heart, and kidneys of the rats. Our results have shown that adrenaline stress causes a decrease in the concentration of hemoglobin, LHP, SOD activity and increase in activities of AST, GP, GR, and GSH content in the blood of rats. Stress induced by adrenaline was accompanied by decrease in CP content, activities of SOD, CAT, and increase in the glutathione chain of antioxidant defense system in the liver of the animals while in the heart and kidneys, there was an increase in oxidative stress parameters and decrease in antioxidant enzyme activities (SOD, CAT, GP, GR). The administration of ethanolic extract of nettle caused an increase within the physiological range in the erythrocytes and leucocytes content, hemoglobin concentration, and normalization of protein metabolism (decrease in the activity of AST and increase in protein concentration) in the blood of the stressed rats. The activation of the antioxidant defense system (increase in activities of SOD, GP, CAT, GR) and inhibition of free radical processes (decrease in concentration of LHP, TBA-active products and $C P$ ) was observed in the tissues of animals of $\mathrm{D}_{2}$ and $\mathrm{D}_{3}$ groups. Our results suggested that using a complex of biologically active substances of the common nettle ethanolic extract prevents metabolic disorders and stresses of different etiology through the activation of the antioxidant defense system, the normalization of protein metabolism and stimulation of hematopoiesis both in normal and stressed rats.

Keywords: Urtica dioica L.; nettle extract; adrenalin stress; rat; antioxidant system; free radical processes.

\section{Introduction}

Stress and its impact on various functional systems of the body has been studied for many years and remains an important problem of modern biology and medicine. Stress is considered as a way to achieve a resistance of the organism against the action of extreme factors of different origins. On the other hand, the role of stress as one of the causes of atherosclerosis, ulcerous lesions of the mucous membrane of the stomach and duodenum, heart and liver function impairment, immunodeficiency and cancer diseases is discussed in numerous studies (Gupta et al., 2012; Cai \& Yan, 2013; Gupta et al., 2014; Rabasa \& Dickson, 2016). In this regard, the problems of chemical regulation of stress and the search for biologically active substances which have antioxidant activity (AOA) will always be relevant and are the subject of ongoing research by scientists around the world (Khavrona, 2015; Shkurashivska \& Erstenyuk, 2015). Despite the large amount of work on the subject, there is a need for additional experimental data to expand our knowledge about the mechanisms of action of antioxidants, especially products of natural origin. Therefore, the search for new drugs for stress correction, as well as the comprehensive use of antioxidants and products of natural origin as stress correctors, has of great practical importance (Mizutani \& Masaki, 2014; Paidi et al., 2014; Ahn, 2017).

Medicinal plants, which represent the raw materials of Ukraine, are the real resources of biologically active substances (BAS). The use of environmentally safe non-traditional raw materials of plant origin, as phytoextracts in the manufacture of food additives and drugs, allows easy and quick elimination of the shortage of essential nutrients, improvement of the state of the organism against unfavourable environmental factors, thereby reducing the morbidity and instead prolonging human and animal life (Abuajah et al., 2015; Zhang et al., 2015; Yakimova et al., 2015; Woo et al., 2017).

Biologically active substances of medicinal plants have advantages over synthetic compounds because their chemical nature is similar to compounds in the body. These substances are contained in an easily digestible form and optimal concentrations, have higher physiological activity, compared with synthetic analogs, are less toxic, and do not 
cause serious side effects. They have a wide range of pharmacological activity and can be used for a long time. It is known that the best plant antioxidants are phenols, carotenoids, ascorbic acid, and others.

It is important to note that antioxidant activity depends not only on the quantitative but also on the qualitative composition of the biologically active substances, as well as its synergistic effect, for example, flavonoids with ascorbic acid (Lindblad et al., 2013; Gorovaya et al., 2015; Zagayko et al., 2017). Natural antioxidants, as a rule, suppress the reaction of free radical oxidation by binding free radicals and helping in the formation of stable chemical compounds, thereby providing optimal conditions for metabolism and ensuring the normal growth of cells and tissues.

In our research, we used common nettle (Urtica dioica L.) as a source of biologically active compounds that can potentially be used as stress correctors. The nettle is characterized by a multivitamin, antibacterial, antidiabetic, choleretic, anti-inflammatory, hemostatic, and tonic effect. It stimulates metabolism, increases the muscle tone of the internal organs, improves the activity of the cardiovascular and respiratory systems, the liver, reduces alcohol intoxication, strengthens the mucus and exhibits adaptogenic action (Chendey et al., 2013; Salih, 2015; Zemmouri et al., 2017; Namazi et al., 2018). Nettle leaves used as an antimicrobial, antihypertensive, and anti-tumour agent (Teloa et al., 2017).

The high pharmacological properties of common nettle are determined by diverse chemical composition. This herb contains mono- and dibasic carboxylic acids (formic, butyric, oxalic, succinic, and fumaric), oxyacids (lactic, citric, chinic, gallic). The nettle includes the whole range of essential and non-essential amino acids, lipids and fatty acids, nitrogen-containing compounds, essential oils, steroids, lectins, lignans, coumarins, histamine, pigments, vitamins $\mathrm{B}_{1}, \mathrm{~B}_{2}, \mathrm{C}, \mathrm{E}, \mathrm{K}, \mathrm{PP}$, carotene, tannins, flavonoids, trace elements $(\mathrm{Cu}, \mathrm{Zn}, \mathrm{Fe}, \mathrm{Mg}, \mathrm{Pb}, \mathrm{Mn})$ and macroelements $(\mathrm{K}, \mathrm{Ca}, \mathrm{P}, \mathrm{Na})$. Stems and leaves are covered with hairs containing silicon (Kopyt'ko et al., 2011; Ahmed et al., 2012; Salih, 2015; De Vico et al., 2018). The dry nettle preparation contains about $35 \%$ crude protein, $23 \%$ - carbohydrates, $1 \%$ - lysine, $0.32 \%$ - cystine, $0.52 \%$ - methionine (Rutto et al., 2013).

Taking into account that the nettle contains a large complex of natural antioxidants, great stocks of environmentally friendly raw materials on the territory of Ukraine, as well as the need to select special conditions for their extraction, all this leads to the development of new drugs and nutritional supplements from the nettle extract to increase adaptive capacity and correction of metabolic disorders in the organism of humans and animals.

In previous studies, we used water and $20 \%, 40 \%, 60 \%, 70 \%$, and $90 \%$ ethanolic extracts of common nettle (Urtica dioica L.). Its radicalabsorbing capacity (RAC) was determined (Molyneux, 2004), and also the effect of each extract on the content of TBC-active products and carbonyl groups of proteins in rat liver homogenate in vitro was studied (Buchko et al., 2016). As a result of our experiments, it was found that $40 \%$ ethanolic extract of nettle is characterized by high RAC, and also that it most efficiently reduced the formation of free radical products in vitro, which can testify to its high antioxidant activity.

Therefore, this extract was used for further studies in order to determine its effect on metabolic processes in the body of rats under the norm and stress condition.

\section{Materials and methods}

The upper part of the nettle stem was used in the experiment. Common nettle was harvested in environmentally friendly areas of Lviv region. Plants were dried in accordance with the standard requirements for medicinal herb preparation - in a dark, dry and ventilated place. The dried raw material was ground in a mortar, sifted through a sieve with a diameter of $1.5 \mathrm{~mm}$ and placed in an extractor. Extraction was carried out at the temperature of $20^{\circ} \mathrm{C}$ for 8 days with stirring. Water-alcohol solution containing $40 \%$ ethanol was used as an extracting agent. The ratio of dry nettle and extracting agent is 1:20 (m/V). After extraction, the extract was filtered and evaporated. In our studies, we used the extract with a concentration of $2.5 \mathrm{mg} / \mathrm{mL}$.
All experiments were conducted in a vivarium of the Institute of Animal Biology of NAAS. Wistar male rats with body weight 180-200 g were divided into 4 groups: control $(C)$ and 3 experimental $\left(D_{1}, D_{2}, D_{3}\right)$, each containing 7 animals. The animals were housed under standard laboratory conditions with free access to drinking water and feed. Experiments were carried out in accordance with the requirements of European Convention for the Protection of Vertebrate Animals Used for Experimental and Other Scientific Purposes (Strasbourg, 1986) and the national General Ethical Principles of Experiments on Animals (Kyiv, 2001). Control and experimental rats were fed a standard diet for laboratory animals.

The animals of the experimental groups $\mathrm{D}_{2}$ and $\mathrm{D}_{3}$ received $40 \%$ nettle extract in a dose $5 \mathrm{~mL} / \mathrm{kg}$ of body weight for 4 weeks. Rats of the control group $(C)$ and the experimental group $\left(D_{1}\right)$ drank an appropriate dose of ethanol. On the 29th day of the experiment, stress was stimulated in animals of $\mathrm{D}_{1}$ and $\mathrm{D}_{3}$ groups by intramuscular administration of $0.1 \%$ adrenaline hydrochloride at a dose of $1 \mathrm{mg} / \mathrm{kg}$ of body weight while the rats of $\mathrm{C}$ and $\mathrm{D}_{2}$ groups were administered an appropriate dose of physiological saline. 24 hours after the administration of adrenaline, the animals of the control and experimental groups were decapitated under ether anesthesia.

Samples of blood, liver, heart, and kidney were collected. All procedures on tissues were carried out at $4{ }^{\circ} \mathrm{C} .1 \%$ solution of heparin was used as an anticoagulant. The blood plasma was separated by centrifugation at $700 \mathrm{~g}$ for 15 minutes, and the erythrocytes were washed three times with $0.150 \mathrm{M} \mathrm{NaCl}$ solution, then a suspension of cells was centrifuged at $700 \mathrm{~g}$ for $5 \mathrm{~min}$. Indicators of the antioxidant system were determined in erythrocyte hemolysates. The tissue samples were homogenized $(1 / 10, \mathrm{~m} / \mathrm{V})$ in $50 \mathrm{mM}$ tris- $\mathrm{HCl}$ buffer $(\mathrm{pH} 7.4)$.

Hematological parameters (number of erythrocytes and leukocytes in the Goriayev chamber) were determined in the blood and hemoglobin concentration was studied by the hemoglobin-cyanide method. In the erythrocytes hemolysates and tissue homogenates, the activity of superoxide dismutase (SOD, EC 1.15.1.1) was evaluated by the level of inhibition of the rate of NBT-reduction in the presence of NADH and phenasine methosulfate. Catalase (CAT, EC 1.11.1.6) activity was measured by monitoring formation of a stable coloured complex of hydrogen peroxide and molybdenum salts. Glutathione peroxidase (GP, EC 1.11.1.9) activity was determined by the rate of glutathione oxidation in the presence of tert-butyl hydroperoxide, and glutathione reductase (GR, EC 1.6.4.2) - by the rate of glutathione recovery in the presence of NADPH. Reduced glutathione (GSH) was quantified by the interaction of SH-groups of glutathione with 5,5'-dithio-bis(2-nitrobenzoic acid) (Vlizlo, 2012). In blood plasma and tissue homogenates, the concentration of lipids hydroperoxides (LHP) was determined by reaction with ammonium thiocyanate. TBA-active products were measured by reaction between malonic dialdehyde and thiobarbituric acid; carbonyl group of proteins (CP) was evaluated by the interaction of carbonyl groups of amino acids with 2,4-dinitrophenylhydrazine (Vlizlo, 2012). The total protein in blood plasma was determined by the Lowry method, and the activities of the alanine aminotransferase (ALT, EC 2.6.1.2) and aspartate aminotransferase (AST, EC 2.6.1.1) - using the kits "Simko LTD". The absorbance values were measured on a spectrophotometer "Unico" 1205 (USA). At the beginning and at the end of the experiment, the rats were weighted. The clinical status and health of animalswere monitored during the study.

The differences between the values in the control and experimental groups were determined using the ANOVA, where the differences were considered significant at $\mathrm{P}<0.05$ (with Bonferroni correction). The results were defined as means \pm standard error $(x \pm S E)$.

\section{Results}

Our results showed that in the blood of rats, the hemoglobin content was lower by $11 \%(\mathrm{P}<0.05)$ in comparison with control due to the stress caused by adrenaline. In the stressed animals which received the nettle extract, hemoglobin concentration was significantly higher in the blood on $15 \%(\mathrm{P}<0.001)$ compared with rats of group $\mathrm{D}_{1}$ (Fig. 1). 
Administration of the nettle extract to the animals of groups $\mathrm{D}_{2}$ and $\mathrm{D}_{3}$ was accompanied by elevation of erythrocytes level by 1.3 and 1.6 times $(\mathrm{P}<0.001)$, respectively. The number of erythrocytes in the blood of the rats of group $\mathrm{D}_{3}$ was higher by 1.4 times than in the animals exposed to stress $(\mathrm{P}<0.001)$ (Fig. 2).

On the other hand, the number of leukocytes in the blood did not differ significantly between groups, but a tendency to increase its content in the rats of group $\mathrm{D}_{2}$ was observed (Fig. 3).

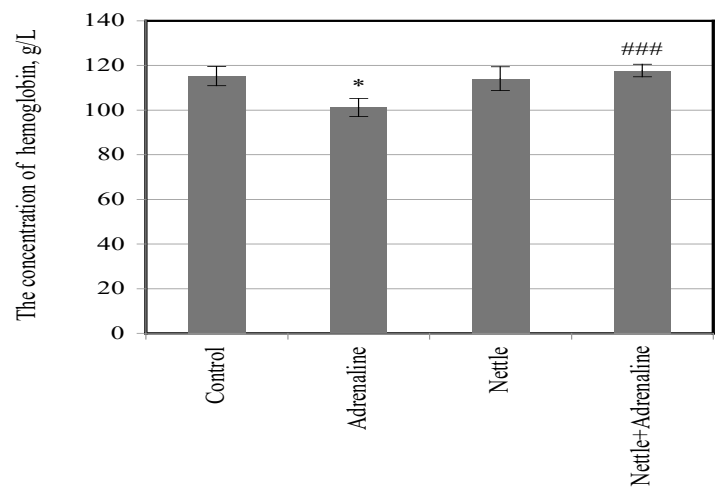

Fig. 1. The concentration of hemoglobin in blood $(x \pm S E, n=7)$ :

* - the difference is statistically significant between control and experimental animals $(*-\mathrm{P}<0.05 ; * *-\mathrm{P}<0.01 ; * * *-\mathrm{P}<0.001)$;

\# - the difference is statistically significant compared with animals of experimental group $\mathrm{D}_{1}\left({ }^{\#}-\mathrm{P}<0.05 ;{ }^{\#}-\mathrm{P}<0.01\right.$; $\left.{ }^{\# \#}-\mathrm{P}<0.001\right)$;

$\mathrm{C}$ - animals of control group; $\mathrm{D}_{1}$ - animals administered $0.1 \%$ solution of adrenaline hydrochloride on the 29th day of the experiment;

$D_{2}$ - animals, received $40 \%$ extract of nettle for 4 weeks; $D_{3}$ - animals received $40 \%$ extract of nettle for 4 weeks and were exposed to $0.1 \%$ solution of adrenaline hydrochloride on the 29th day of the experiment

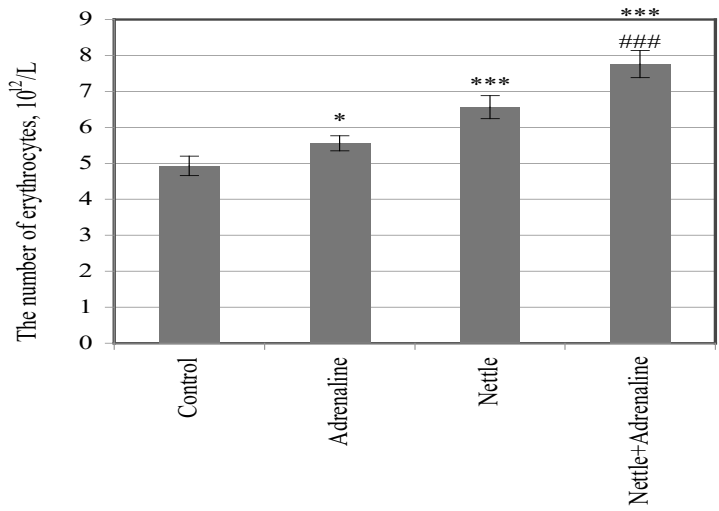

Fig. 2. The number of erythrocytes ( $x \pm S E, n=7)$ : see Fig. 1

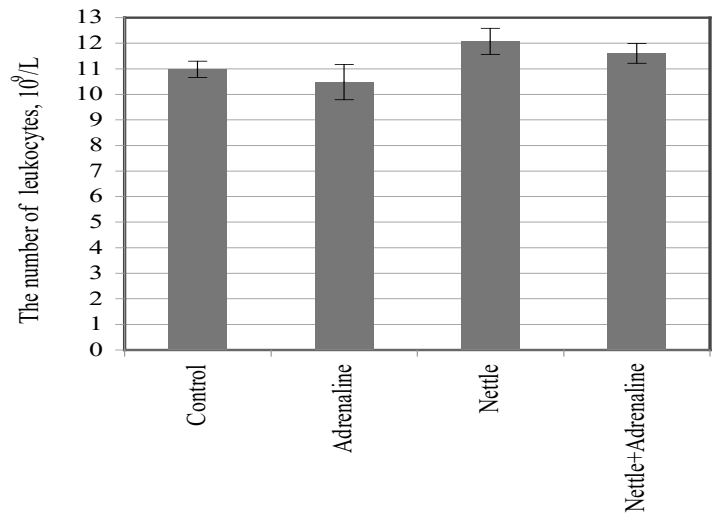

Fig. 3. The number of leukocytes $(x \pm S E, n=7)$ : see Fig. 1

The administration of nettle extract on the background of adrenalin stress caused changes in the protein metabolism of the rats. Thus, the increase in concentration of total protein in the blood plasma of experi- mental animals of the groups $\mathrm{D}_{1}$ and $\mathrm{D}_{2}$ by $6 \%(\mathrm{P}<0.05)$ and $9 \%(\mathrm{P}<$ $0.01)$ respectively was observed compared with control. The highest protein concentration was found in the plasma of $D_{2}$ rats $(107.1 \mathrm{~g} / \mathrm{L})$ exposed to the nettle extract, which may indicate the activation of anabolic processes in their body (Fig. 4).

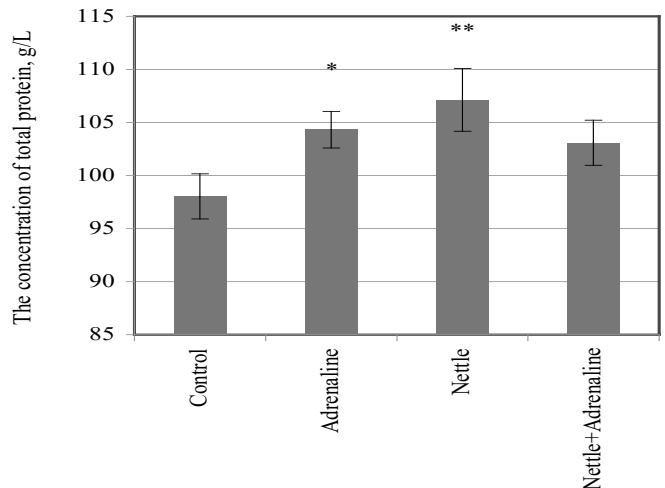

Fig. 4. The concentration of total protein in the plasma $(x \pm$ SE, $n=7)$ : see Fig. 1

The investigated substances most significantly influenced the activity of AST. At the same time, in blood plasma of rats under the action of adrenaline (group $\mathrm{D}_{1}$ ), AST activity was significantly higher by $31 \%$ compared with control $(\mathrm{P}<0.001)$, while the activity of ALT in the blood of animals of all experimental groups did not change (Fig. 5). The administration of the nettle extract resulted in a significant decrease in AST activity in the blood of $\mathrm{D}_{2}$ rats by $38 \%$ compared with the control $(\mathrm{P}<0.01)$ and by $67 \%$ compared to the stressed animals of $\mathrm{D}_{1}$ group $(\mathrm{P}<0.001)$. In the rats of $\mathrm{D}_{3}$ group the reduced activity of AST by $30 \%$ was observed compared with $\mathrm{D}_{1}$ group $(\mathrm{P}<0.001)$.

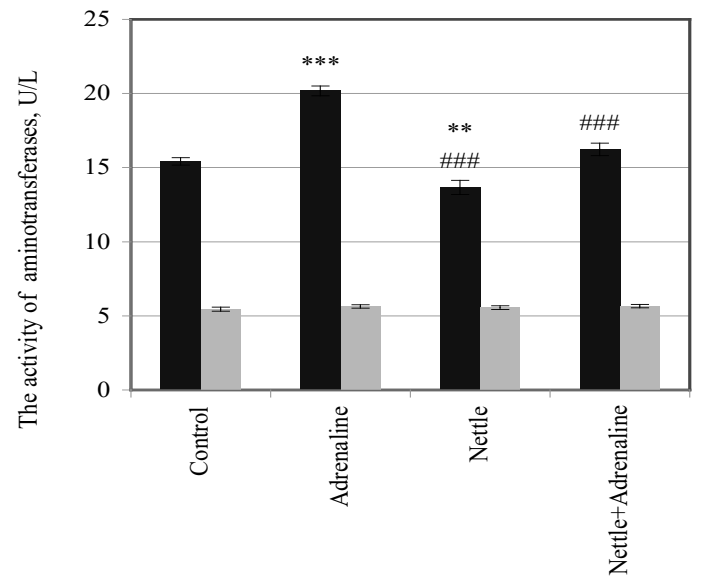

Fig. 5. The activity of aminotransferases in the plasma:

- - aspartate aminotransferase (AST), - - alanine aminotransferase (ALT); $\mathrm{x} \pm \mathrm{SE}, \mathrm{n}=7$; see Fig. 1

It is well known that stress of any etiology causes the activation of free radical damage to the lipid and protein components of membranes in the body. Our results showed that the concentration of the initial products of lipid peroxidation - lipid hydroperoxides in the plasma of $\mathrm{D}_{1}$ rats was significantly lowered by 1.6 times $(\mathrm{P}<0.001)$, while in the kidneys it increased by $18 \%(\mathrm{P}<0.05)$ in comparison with control (Fig. 6). In the kidneys and heart of the same group, the content of the final metabolites of lipid peroxidation - TBA-active products increased significantly compared with control by 1.4 and 1.5 times $(\mathrm{P}<0.001)$ (Fig. 6, 7). In the kidneys of $\mathrm{D}_{1}$ group animals, the content of carbonyl groups of protein increased significantly by 2.5 times compared to the control animals $(\mathrm{P}<0.001)$.

Administration of the nettle extract was accompanied by a 1.2 times decrease in the concentration of TBA-active products in the plasma of $\mathrm{D}_{2}$ rats, compared with control and $\mathrm{D}_{1}$ group $(\mathrm{P}<0.01)$, at the same time the content of $\mathrm{CP}$ in the plasma of $\mathrm{D}_{3}$ rats decreased by 1.5 times 
compared with control and $\mathrm{D}_{1}$ group $(\mathrm{P}<0.05)$. Also, we observed the decrease in lipid hydroperoxides by 1.3 times $(\mathrm{P}<0.05)$ and $\mathrm{CP}-$ by 2 times $(\mathrm{P}<0.001)$ in the liver of animals of $\mathrm{D}_{2}$ group compared with control. Our results have shown the increase in the carbonyl groups of protein in the liver of rats administered the nettle extract on the background of stress by 1.8 times $(P<0.05)$ compared with animals of $D_{1}$ group. In these animals, the decrease in lipid hydroperoxides was observed by 1.5 times $(\mathrm{P}<0.01)$ compared to control, and 1.6 times $(\mathrm{P}<$ 0.01 ) compared with $\mathrm{D}_{1}$ group (Fig. 6-8). In the kidneys and especially in the heart of rats, the administration of nettle extract led to the decrease in concentration of products of free radical damage to membranes under norm ( $\mathrm{D}_{2}$ group) and under stress $\left(\mathrm{D}_{3}\right.$ group) compared with only stressed animals ( $\mathrm{D}_{1}$ group). Thus, in the kidneys of $\mathrm{D}_{3}$ rats, the lipid hydroperoxide content decreased by $16 \%(\mathrm{P}<0.05)$. It was found that in the heart of $\mathrm{D}_{3}$ animals, the concentration of LHP decreased by $13 \%$ $(\mathrm{P}<0.05)$, TBA-active products - by $26 \%(\mathrm{P}<0.001)$ in $\mathrm{D}_{2}$ group, and $\mathrm{CP}-$ by 1.6 times $(\mathrm{P}<0.05)$ and 2.6 times $(\mathrm{P}<0.001)$ respectively in rats of $\mathrm{D}_{2}$ and $\mathrm{D}_{3}$ groups (Fig. 6-8).

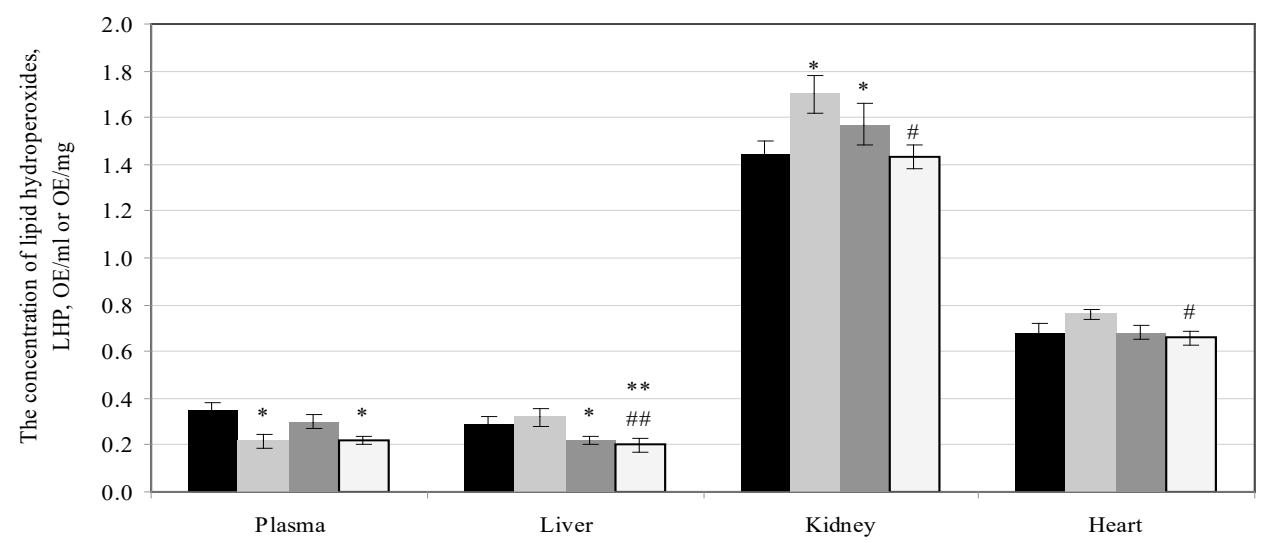

Fig. 6. The concentration of lipid hydroperoxides (LHP, $x \pm$ SE, $n=7$ ): $\mathbf{-}-$ control, $\_-$adrenaline, $\square-$ nettle, $\square-$ nettle + adrenaline; see Fig. 1

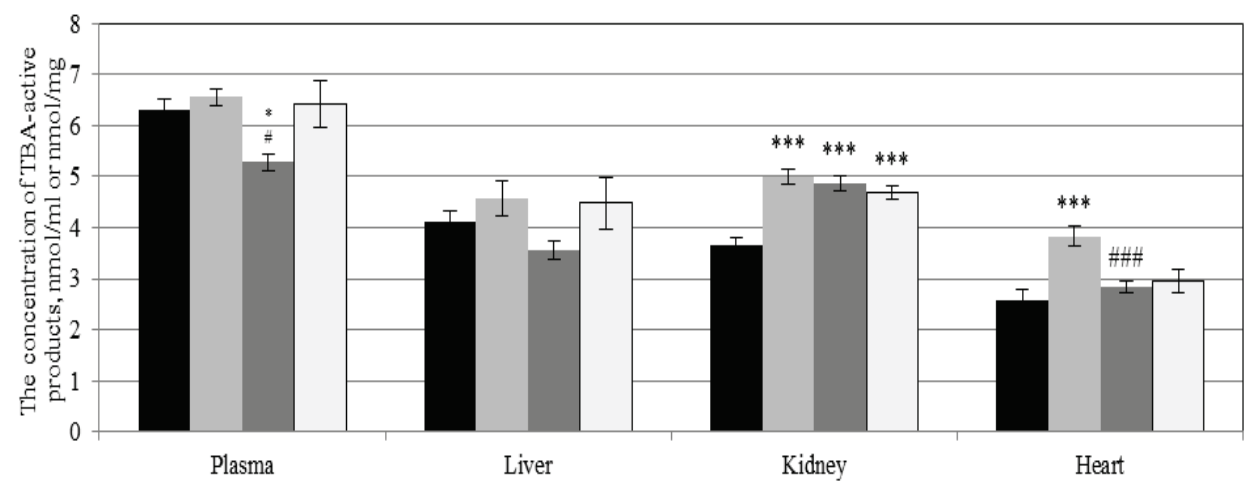

Fig. 7. The concentration of TBA-active products $(x \pm S E, n=7)$ : see Fig. 1,6

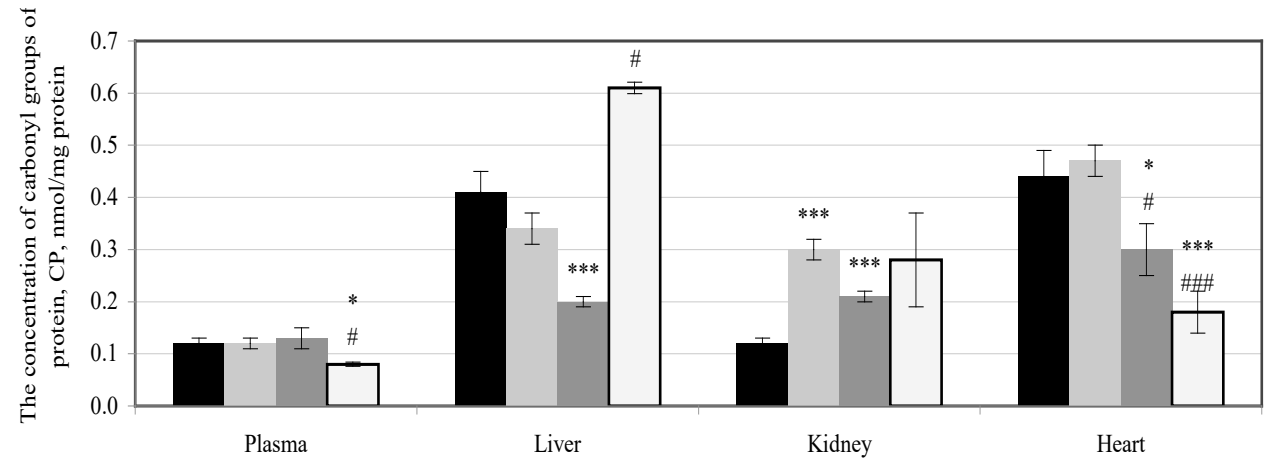

Fig. 8. The concentration of carbonyl groups of protein $(C P, x \pm S E, n=7)$ : see Fig. 1, 6

The activation of free radical processes under stress is a major challenge for the antioxidant defense system in the organism. A sharp decrease in the enzymatic chain of the antioxidant system under the influence of adrenaline was observed in all organs of rats compared with control animals. Thus, the activity of SOD was reduced in erythrocytes of $\mathrm{D}_{1}$ group by 1.4 times $(\mathrm{P}<0.001)$, in the kidneys - by 1.3 times $(\mathrm{P}<$ $0.001)$, and in the heart - by 2 times $(P<0.001)$. Enzyme activity in erythrocytes of rats which were administered nettle extract $\left(D_{2}\right)$ was significantly higher than in the heart of $\mathrm{D}_{1}$ animals - by $14 \%(\mathrm{P}<0.05)$. Administration of nettle extract to stressed animals (group $\mathrm{D}_{3}$ ) was accompanied by increasing of SOD - activity in the kidneys by 1.2 times $(\mathrm{P}<0.001)$ and in the heart - by 1.6 times $(\mathrm{P}<0.001)$ (Fig. 9).
The activity of another key enzyme of antioxidant defense system catalase under the influence of adrenalin also significantly decreased in the liver and heart - by 1.4 times compared to control animals $(\mathrm{P}<$ $0.001)$. The activities of CAT as well as SOD significantly increased in the tissues of the rat administered the nettle, both in norm and under stress, compared to the animals exposed only to adrenalin, and were lower in the control group. Catalase activity in the kidney of the rat of $\mathrm{D}_{2}$ group was higher in 1.5 times, and in the heart of $\mathrm{D}_{3}$ group - by $11 \%$, compared to $\mathrm{D}_{1}$ group (Fig. 10).

Our results showed a compensatory enhancement of the glutathione chain of the antioxidant system in response to the activation of free radical oxidation and a decrease in the activity of such enzymes as SOD 
and CAT under the stress. In erythrocytes of $\mathrm{D}_{1}$ animals, there was a tendency to increase in activities GP, GR and at the same time GSH concentration was 1.6 times higher $(\mathrm{P}<0.001)$. The administration of adrenaline to animals of $\mathrm{D}_{1}$ group was accompanied by a $28 \%$ increase in the content of GSH in the liver ( $\mathrm{P}<0.001)$, in the kidneys - by 1.25 times $(\mathrm{P}<0.001)$ and in heart - by 1.7 times $(\mathrm{P}<0.001)$, while the activity of the GP decreased in the heart by $38 \%(\mathrm{P}<0.001)$, and GR in the kidneys - by $14 \%(\mathrm{P}<0.05)$ compared to the control animals. Administration of the nettle extract to the $\mathrm{D}_{2}$ group resulted in the increase GSH content by 1.7 times $(\mathrm{P}<0.001)$ in the erythrocytes, in the kidneys 1.6 times $(\mathrm{P}<0.001)$, and in the heart -1.4 times $(\mathrm{P}<0.001)$ compared to control animals. In the kidneys of $\mathrm{D}_{2}$ group, the concentration of GSH was 1.6 times higher $(\mathrm{P}<0.001)$ compared to stressed animals
( $\mathrm{D}_{1}$ group) with a simultaneous decrease in GR activity in animals of this group by 1.2 times $(\mathrm{P}<0.05)$ compared with control (Fig. 11-13).

Administration of the nettle extract to rats exposed to adrenaline led to a decrease in the activities of GP and GR in erythrocytes by 1.7 times $(\mathrm{P}<0.001)$ and 1.4 times, respectively, in comparison with the control, and compared with the stressed animals (group $\mathrm{D}_{1}$ ) by 2.2 times $(\mathrm{P}<0.001)$ and 1.5 times $(\mathrm{P}<0.001)$ respectively. The GSH content in erythrocytes of the $\mathrm{D}_{3}$ group decreased by 1.2 times compared with stressed animals of the $\mathrm{D}_{1}$ group $(\mathrm{P}<0.001)$ but was higher by 1.3 times than the control $(\mathrm{P}<0.001)$. In the liver of animals of $\mathrm{D}_{3}$ group, GP activity increased by 1.2 times $(\mathrm{P}<0.001)$ compared with control and by 1.3 times $(\mathrm{P}<0.001)$ compared to $\mathrm{D}_{1}$ group, while the glutathione content increased 1.4 times $(\mathrm{P}<0.001)$ compared to control (Fig. 11).

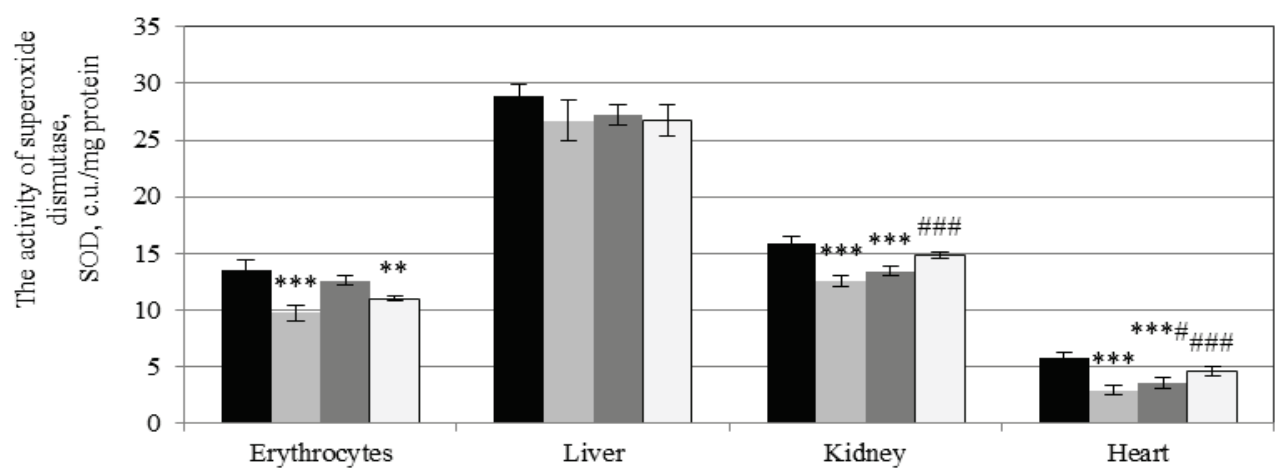

Fig. 9. The activity of superoxide dismutase (SOD, $x \pm S E, n=7$ ): see Fig. 1, 6

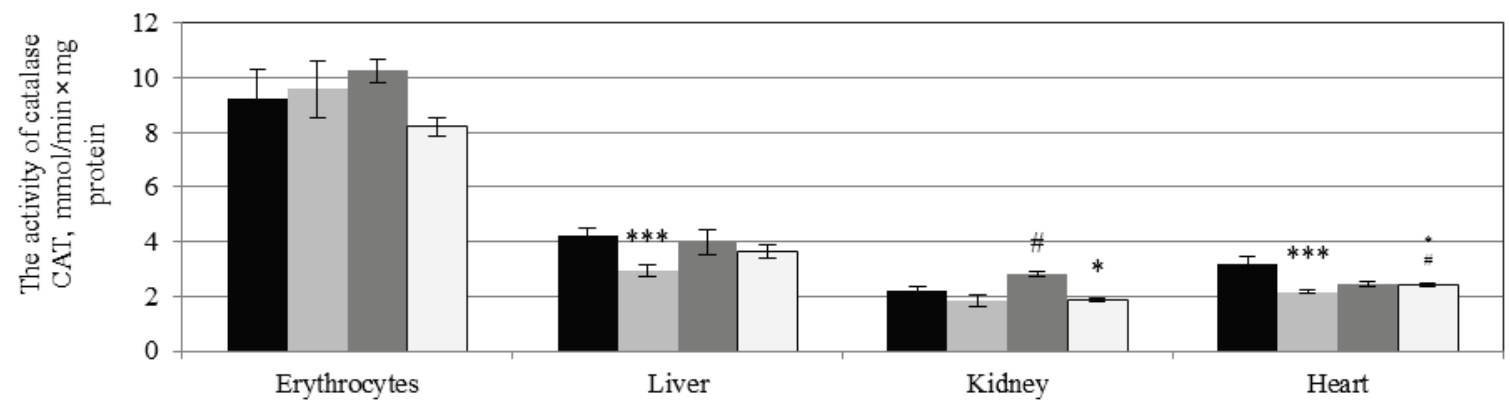

Fig. 10. The activity of catalase (CAT, $x \pm S E, n=7$ ): see Fig. 1,6

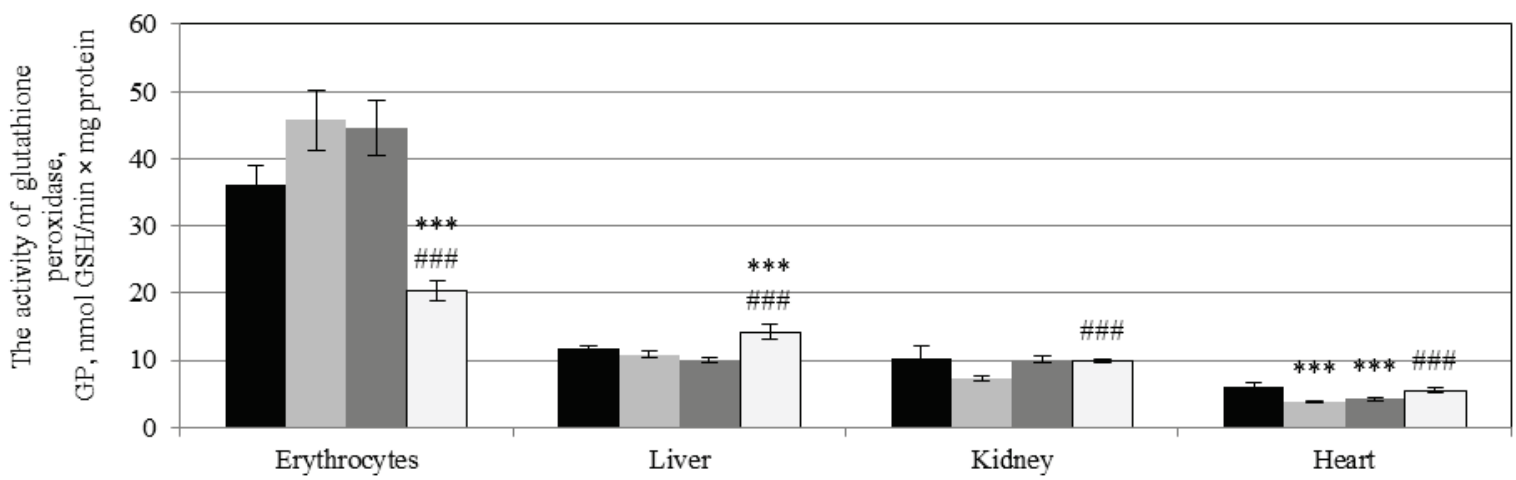

Fig. 11. The activity of glutathione peroxidase (GP, $x \pm$ SE, $n=7$ ): see Fig. 1, 6

In the heart of $\mathrm{D}_{3}$ rats, the activity of GR was 2.7 times higher than the control and $\mathrm{D}_{1}$ groups $(\mathrm{P}<0.001)$, and the concentration of GSH increased 2.5 times compared with control $(\mathrm{P}<0.001)$. As can be seen from Figures 12 and 13, in the kidneys of animals of $\mathrm{D}_{3}$ group, a significant increase in the activity of the GP compared to $\mathrm{D}_{1}$ group was observed, and at the same time, an increase in the content of GSH compared to control by 1.5 times $(\mathrm{P}<0.001)$ was revealed.

Thus, it was found that the glutathione chain of the antioxidant defense system reacted most strongly to the complex effect of adrenaline on the background of nettle extract watering in the heart of $\mathrm{D}_{3}$ rats compared with control animals and in those exposed only to stress. Weigh- ing the animals at the beginning and at the end of the experiment showed the increase of live weight in the control rats and animals of two experimental groups $\left(\mathrm{D}_{2}\right.$ and $\left.\mathrm{D}_{3}\right)$, which were given the nettle extract and once on the background of adrenalin stress, on an average of 43 grams for 30 days. The weight of animals exposed to stress $\left(D_{1}\right)$ increased only by 20 grams.

\section{Discussion}

It is well known that stress, including short-term stress, the model of which is used in our studies, is accompanied by a disorder of meta- 
bolic processes in the whole organism. Administration of adrenaline hydrochloride to rats led to the activation of glycogenolysis and gluconeogenesis in the liver, as well as the inhibition of glucose utilization by tissues and hyperglycemia (Joshi et al., 2015; Qaid, 2016; Zagayko et al., 2017). Hyperglycemia increases the rate of mobilization and release of non-esterified fatty acids into the blood, which results in the enhanced synthesis of low-density lipoproteins and their oxidative modification. On the other hand, the utilization of excessive amounts of adrenaline leads to the formation of adrenochrome (a product of the oxidation of adrenaline by free radicals) and free radicals (semiquinone, etc.) with the further intensification of oxidative damage to molecules (Gupta et al., 2014; Shkurashivska \& Erstenyuk, 2015; Rabasa \& Dickson, 2016). Our experiments have shown that free radical processes on the one hand, and antioxidant protective mechanisms in the body of animals on the other, under normal conditions and, especially under stress, have tissue specificity. Our data support the idea that greater resistance to adrenaline lesions can be found in tissues which are characterized by active metabolic processes and the synthesis of components of the antioxidant defense system (such as blood and liver) (Khavrona, 2015).
Low concentrations of LP (LHP and TBA-active products) and oxidative modification of proteins $(\mathrm{CP})$ with simultaneous activation of glutathione chain of the antioxidant defense system in the erythrocytes and liver of rats were detected under the action of adrenaline.

Compensatory enhancement in the functioning the glutathione system in the liver may be due to the high metabolic activity of this organ, which intersects the processes of metabolism of carbohydrates, fats, and amino acids. In addition, $20 \%$ of the liver volume is mitochondria, where a large number of active forms of oxygen are formed.

Increase in the formation of active forms of oxygen leads to intensifying processes of peroxide oxidation, as opposed to activation of the antioxidant defense system. An increase in the concentration of GSH in red blood cells, liver, kidneys and heart under stress can be explained by its compensatory synthesis and recovery from the oxidized form by increased activity of GR. This enzyme depends on NADPH, whose regeneration is enhanced when adrenaline is administered into the body and activation of the energy metabolism in the liver and the development of hyperglycemia occurs (Cai \& Yan, 2013; Gupta et al., 2014; Khavrona, 2015; Zagayko et al., 2017).

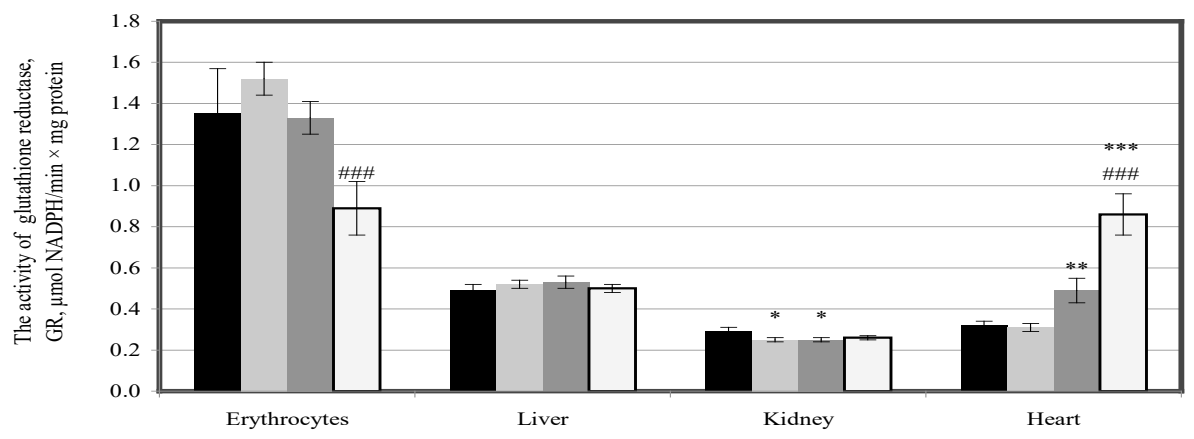

Fig. 12. The activity of glutathione reductase (GR, $x \pm S E, n=7)$ : see Fig. 1,6

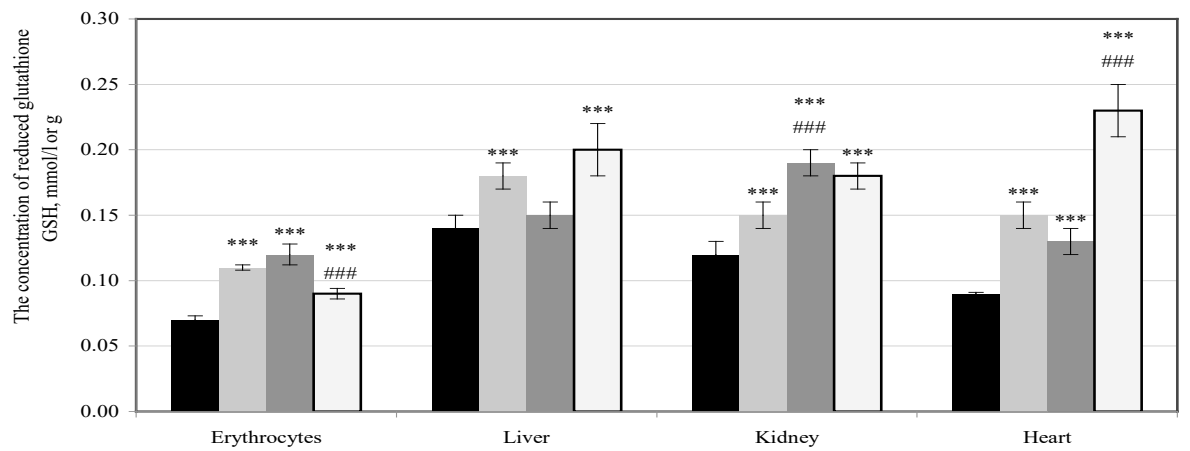

Fig. 13. The concentration of reduced glutathione ( $G S H, x \pm S E, n=7)$ : see Fig. 1,6

Another reason for the increased activity of glutathione chain of the antioxidant defense system in erythrocytes and liver of rats under the influence of adrenaline is the compensation for a sharp decrease in the activity of SOD and CAT of these tissues compared with the control.

In our studies the kidneys and heart of rats were the least resistant to hyperadrenalemia because we found a significant increase of all products of free radical processes and a low activity of the all antioxidant enzymes in these tissues after administration of this hormone, which may indicate an exhaustion of the antioxidant defense system under the influence of adrenaline and the development of oxidative stress in these organs. According to the literature data, one of the reasons for a sharp decrease in antioxidant enzyme activity in the heart and kidneys is adrenaline damage to these tissues, which is accompanied by a decrease in the content of trace elements - metals with variable valency $(\mathrm{Cu}, \mathrm{Zn}$, and $\mathrm{Fe})$. These metals are cofactors of enzymes of antioxidant protection; energy metabolism and ion transport systems and can lead to their deactivation and reduction of their synthesis (Birben et al., 2012; Khavrona, 2015).

The imbalance of the proteinase system in the blood of the animals (a sharp increase in AST in the plasma on the background of an invariable activity of ALT) under the action of adrenalin was established.
These data may indicate necrotic damage to the myocardium caused by the intramuscular administration of adrenaline in the applied dose and, as a result, the release of enzymes into the blood. It is well known that the increase in activity of aminotransferases is used in clinical trials as a marker of cardiac lesions (Chendey et al., 2013; Gupta et al., 2014). The decrease in the concentration of hemoglobin in the blood of rats under the influence of stress caused by adrenalin can explain its partial destruction, which ultimately can affect the erythropoiesis, violations of the respiratory function of the blood and iron deficiency anemia. The lower live weight in the rats after adrenaline injection at the end of the experiment compared with control, and especially with the animals which received the nettle extract, may indicate a negative effect of stress on the physiological state of their body as a whole. The decrease of body weight in the animals exposed to stress compared with the other groups of rats is consistent with the literature data on the adverse effects of adrenaline on live weight (Rabasa \& Dickson, 2016).

We chose the common nettle for the study because it has been a well known medicinal plant since ancient times and is widely distributed in Ukraine, its collection is economically profitable, environmentally justifiable, and harvesting can take place for a long time (May - 
August) without loss of useful properties of raw materials. In order to maximally remove natural antioxidants from plant material and convert them into an active form, it is necessary to carefully select the extractant and extraction conditions. In our previous studies, the following regimes of extraction for the common nettle were established: the dispersion of the raw material particles was $1.5 \mathrm{~mm}$, the ratio of the raw material: extractant (nettle: ethanol) was 1:20, the extraction temperature was 20 ${ }^{\circ} \mathrm{C}$ for 8 days (Buchko et al., 2016). After extraction, filtration, and dehydration, the extracts were used at a concentration of $2.5 \mathrm{mg} / \mathrm{mL}$. We did not investigate the qualitative and quantitative composition of the obtained aqueous and $20 \%, 40 \%, 60 \%, 70 \%$ and $90 \%$ ethanolic extracts of common nettle, but used literature data (Kopyt'ko et al., 2011; Ahmed et al., 2012; Seliya \& Kothiyal, 2014). According to studies by other authors (Gaballu et al., 2015; Jakubczyk et al., 2015; Ghasemi et al., 2018) and our hypothesis, $90 \%$ ethanol can best remove antioxidants such as carotenoids and chlorophyll from common nettle, which provides high radical-absorbing activity of this extract and reduces in the content of carbonyl groups of proteins in vitro studies. $70 \%$ ethanol provides a more complete extraction of phenolic compounds (hydroxycinnamic acids and flavonoids), which is confirmed by the high radical-absorbing activity of this extract. $40 \%$ and $60 \%$ extracts contain a large number of antioxidants such as organic acids and vitamins (in particular, ascorbic acid) that reduce the formation of TBAactive products and $\mathrm{CP}$.

Taking into account the positive effects of nettle extracts on animal metabolism, we used $40 \%$ extract in our studies to increase the antistress ability of the body. However, in the literature, there is a large number of controversial data on this issue. So, according to studies by Namazi et al. (2018), 70\% ethanolic extract of Urtica dioica L. prevents the occurrence of atherosclerotic lesions in the aorta rats, which is associated with a positive effect on the lipid profile of the serum, but does not significantly affect the state of antioxidants and manifestations of oxidative stress. On the other hand, Mirtaghi et al. (2016) noted that $70 \%$ ethanolic extract of nettle (Urtica dioica L.) is characterized by antibacterial and antioxidant activity, which may be due to the high content of phenolic compounds and the presence of alkaloids, tannins, and terpenoids in its composition, which confirms the use of this plant for the treatment of urinary tract infections.

Johnson et al. (2013) indicate that to obtain the desired anti-inflammatory effect, the nettle extraction was carried out with a mixture of water, hexane, methanol, and dichloromethane. The authors received a more effective anti-inflammatory drug than traditional tincture of nettles for the treatment of inflammatory disorders, especially arthritis. Salih (2015) states that $95 \%$ of nettle extract protect the nephrons from oxidative damage, due to the high content of phenols and high antioxidant activity. Wolska et al. (2015) indicate the ability of both aqueous and $70 \%$ ethanolic extracts to increase the activity of catalase in isolated monocytes of leukemia-affected individuals, although the best effect on enzyme activity was characteristic of ethanolic extract of nettle. The normalization of the metabolism under the influence of polyphenols isolated from the nettle is shown in the papers (Güler, 2013; Joshi et al., 2015). Authors Bisht et al. (2017), Zagayko et al. (2017) indicate that the anti-oxidant nettle fraction is rich in flavonoids and phenolic compounds, reduces the activity of acetylcholinesterase and processes of oxidative damage to neurons, activates the antioxidant defense system, and therefore has a positive effect on the treatment of Parkinson's disease, type 2 diabetes, and oncological diseases.

Zemmouri et al. (2017) have established the anti-asthmatic effect of the aqueous nettle extract, but believe that the antioxidant activity of plant extracts is usually associated with their phenolic content. They also pointed out that ecological conditions and differentiated geographical distribution can change the content of phenolic compounds and their derivatives (phenolic acids, flavonoids, etc.) in plants, and thus differ in the antioxidant power of plant preparations. Analysis of literary data suggests that in general, after obtaining aqueous extracts, the amount of bioflavonoids in most medicinal plants does not exceed 30\% of their content in raw materials, and after aqueous-alcoholic extraction, the yield of bioflavonoids varied from $60 \%$ to $85 \%$. These data confirm our own results that the aqueous extract of the common nettle has a low antioxidant activity. To assess the physiological state of animals and to determine the effectiveness of the nettle extract on the organism of animals both under the norm and under oxidative stress caused by the action of adrenaline hydrochloride, we studied morphological parameters of blood because they are very sensitive to changes occurring in organisms, especially under the influence of various stress factors. Our studies confirmed the hematopoietic effects of nettle, rich of microelements, especially iron, zinc and copper on hemopoiesis (the number of red blood cells increased within the physiological norm), antianemic effects (increase of hemoglobin concentration), and stimulation of the respiratory function of blood in non-stressed, as well as stressed rats compared to animals that were exposed to adrenaline. The positive effect of $40 \%$ nettle extract on hematological parameters of rats can be explained by the effect of its components: ascorbic acid, vitamin $\mathrm{E}$ (a part of the erythrocyte membranes), B vitamins and organic acids (citric, malic, succinic acids, etc.). Selenium also affects the oxygen function of hemoglobin (Joshi et al., 2014; Joshi et al., 2015; Zemmouri et al., 2017).

It is known that protein metabolism involves the coordination, regulation, and integration of most chemical transformations in the body. The emergence and spread of excitation, muscle contraction, oxygen transport, blood properties, immune protection, the transmission of hereditary information, etc., is associated with proteins. In addition, proteins are a source of energy (Oltjen et al., 2013).

For a better understanding of the mechanisms of adaptation that occur in animals in response to adverse factors on the background of the introduction of biologically active substances of natural origin, the determination of the intensity of protein metabolism has an important role, in particular the processes of transamination - the inverse transfer of amino groups between amino acids and ketoacids, which is carried out using aminotransferases. AST and ALT are enzymes that act on the intersection of protein, hydrocarbon and fat metabolism. In veterinary and humane medicine, the determination of the activity of aminotransferases in serum is proposed as a sensitive test for the permeability of hepatocyte membranes and cardiomyocytes in the case of liver and heart damage by exogenous or endogenous toxins (Khariv, 2016).

The increase in the concentration of total protein in the plasma of animals which was watered by nettle extract can be explained by the fact that the nettle includes amino acids, citric, formic, silicic acids, which, together with ascorbic acid and flavonoids, increase energy metabolism, oxidationreduction and anabolic processes in the body. The decrease in the activity of AST to the control level, both in the stressed animals and the rats which were watered by only the nettle extract, indicates a normalization of the balance between the synthesis and degradation of protein in the whole organism. According to the literature data, these changes are associated with the positive effect of plant polyphenols (Zagayko et al., 2017). The activation of protein synthesis in the rats, administered $40 \%$ nettle extract, is consistent with the increase in live weight in these groups of animals, and this is also a confirmation of the positive effect of the nettle extract on the general physiological state of the organism compared with stressexposed animals.

The increase in the live weight of animals which were given the nettle extract during the experiment are consistent with the results of other authors who showed a mass increase in rats during treatment with aqueous extract (Juma et al., 2015) and adding 3\% nettle to the diet of sick fish (De Vico et al., 2018), which may indicate the activation of anabolic and immune processes in the body through the action of the nettle component.

It is known from literature data that there are two mechanisms for controlling oxidative stress - the synthesis of an antioxidants of the organism, that are formed in the body (endogenous way) and the introduction of food or additives (exogenous way) (Gupta et al., 2014; Hea et al., 2017). The antioxidant defense system, which includes endogenous and exogenous antioxidants, controls and maintains the stationary level of free radical processes in the body and oxidant-antioxidant equilibrium. The antioxidant reactions in the protective mechanisms are the leading and most powerful chain, since they prevent not only the development of free radical reactions, the accumulation of superoxide anions and peroxides, but also support the high activity of oxidation-reduction processes, provide for the elimination of final oxygen metabolites with 
their involvement in energy metabolism and activation of synthetic processes (Cai \& Yan, 2013; Rabasa \& Dickson, 2016). Data on the functioning of the antioxidant defense system, depending on the physiological state of the organism, should be taken into account when ensuring the preservation and protection of the health of animals and humans. The ratio of indicators of the antioxidant system and the intensity of peroxidation processes is an objective criterion for assessing the antioxidant status and is recommended for timely detection of oxidative stress in the body.

The antioxidant defense system in the organism is represented by enzymatic and non-enzymatic chains. The enzymatic component includes SOD and CAT, which act as an initial chain of protection against superoxide radicals and hydrogen peroxide, respectively. The terminal enzymatic component is glutathione chain - GP and GR that protect from both hydrogen peroxide and organic hydroperoxides. GR provides the regeneration of glutathione from an oxidized form into a recovered state, while glutathione, as an acceptor of the active forms of oxygen, is capable of inhibiting free radical oxidation (Khavrona, 2015). GSH with lipoic acid, L-arginine, coenzyme $\mathrm{Q}_{10}$, melatonin, uric acid, bilirubin, metal-containing proteins, transferrin, and others belongs to non-enzymatic endogenous antioxidants, which are produced during the process of metabolism in the body. Exogenous antioxidants are compounds that are not synthesized in the body and should enter the body with food or supplements. They include vitamin E, vitamin C (for humans and guinea pigs), carotenoids, trace elements (selenium, manganese, and zinc), flavonoids, omega-3, and omega-6 fatty acids, etc.

It is shown that food antioxidants are involved in the detoxification of active forms of oxygen (Choi et al., 2012; Gupta et al., 2012) and help endogenous antioxidants in the neutralization of oxidative stress. Natural antioxidants exhibit their protective effect in a complex manner, therefore the decrease in the content of one leads to a violation in the whole system of antioxidant defense. The deficiency of both endogenous and exogenous antioxidants is one of the causes of numerous chronic and degenerative pathologies since each of them is a substance unique in terms of its structure and antioxidant function and indispensable in the processes of enhanced generation of free radicals (Birben et al., 2012). In this aspect, the study of antioxidant properties of phytoextracts in the body under stressful conditions of different etiologies will always be relevant.

The results of our study showed that the administration of the nettle extract to the animals resulted in a reduction in the content of free radical oxidation of lipid and protein molecules in blood plasma and tissue homogenates in rats. Thus, the concentration of LHP, TBA-active products and CP in plasma, and especially in the liver, heart, and kidney of rats in the $\mathrm{D}_{2}$ group, was lower than in stress-exposed animals and, even somewhere, was lower than in the control. The high antioxidant activity of the $40 \%$ nettle extract in the animal body can be explained by the fact that both water and fat-soluble natural antioxidants were extracted from the nettle. From literature data, it is known that there is a functional connection between ascorbic acid and plant polyphenols in a living organism (Kaledaite \& Bernatoniene, 2011; Spatafora \& Tringali, 2012). Both of these ingredients are contained in the nettle in large quantities. When these compounds in a sufficient amount enter into the body, polyphenols are stabilized with ascorbic acid, or stable polyphenolic complexes that are formed due to the binding of metal ions (which are also numerous in the nettle) inhibit the catalytic oxidation of ascorbic acid. Thus, ascorbic acid regenerates phenolic antioxidants by increasing their concentration, and in turn, ones protect it from oxidative damage (Choi et al., 2012; Lindblad et al., 2013; Carr \& Lykkesfeldt, 2017).

According to this scheme, ascorbic acid interacts with the main antioxidant metabolite of the organism - GSH. Our studies have shown that ascorbic acid, being a natural antioxidant, is a powerful reducing agent and stabilizer of SH-groups of thiols, enzymes, and glutathione. On the other hand, the permanent intake of ascorbic acid in erythrocytes occurs due to the release of oxidized form of ascorbate (dehydroascorbic acid) from the plasma, and the restoration of which occurs due to the presence of the recovered forms of pyridine coenzymes and GSH in the cells (Paidi et al., 2014; Khavrona, 2015). Taking into account that the ascorbic acid molecule contains polar and nonpolar groups, it can inte- ract with both glutathione (tripeptide) and lipid antioxidants ( $\alpha$-tocopherol, phenols), and restores them and enhances antiradical activity.

The basis of the glutathione redox cycle consists of three amino acids, two of which - glutamic acid and glycine are contained in the nettle, which explains the high concentration of GSH in red blood cells and tissues of rats, exposed to the studied extract in the norm, and on the background of stress. Stable high levels of glutathione, as well as the presence in the nettle of a trace element such as Se, which is part of the active center of the GP, can be explained by the activation of this enzyme in the rat body under the influence of the nettle extract.

There were no changes in the catalase activity of erythrocytes between stressed and control rats because the hydrogen peroxide which is formed after dismutation of the superoxide anion radical by SOD was removed by normal (physiologically sufficient) levels of CAT, with the direct involvement of high content of reduced glutathione, since it is the main protector from the toxic effects of $\mathrm{H}_{2} \mathrm{O}_{2}$.

It was noted above; biologically active substances included in the $40 \%$ nettle extract positively influenced the glutathione chain of the antioxidant defense system. This can be explained by the high activity of GP, GR and GSH content and low concentration of LHP, TBA-active products and $\mathrm{CP}$ in the blood and tissues of $\mathrm{D}_{2}$ group compared with adrenaline stressed rats and somewhere with control. Increasing the activity of SOD and CAT, especially in the kidneys and heart of rats under the influence of the nettle is connected with trace elements such as $\mathrm{Cu}, \mathrm{Zn}$, and $\mathrm{Fe}$. It is well known that these microelements are included in the active centers of the mentioned enzymes, activating their synthesis and functioning.

The low activity of the enzymatic chain of the antioxidant defense system in the blood and tissues of the rats of $\mathrm{D}_{3}$ group on the background of the lower level of oxidative stress products relative to the control can be explained by the reduction of metabolites of the free radical-reactions under the influence of the nettle extract antioxidants. In these conditions, there is no need for activating the antioxidant defense system in the organism.

Thus was revealed the activation of anabolic processes, the normalization of metabolism, stimulation of hemopoiesis, and the inactivation of products of free radical reactions in the blood and tissues of rats, which is related to the chemical composition of nettle which contains a complex of biologically active substances with high antioxidant activity. These are primarily polyphenolic compounds (flavonoids), chlorophylls, vitamins $\mathrm{C}$ and $\mathrm{E}$, quercetin, carotenoids, amino acids (glutamic acid and glycine), organic acids and trace elements, which are cofactors of antioxidant enzymes SOD, GP, and CAT. This powerful complex of natural antioxidant substances suppresses the oxidative stress caused by the exposure to adrenaline, binds and restores free radicals, neutralizes it, breaking the chain of free radical reactions. These biologically active compounds provide transformation of free radicals into stable chemical compounds; prevent the destruction of cell membranes, thus developing optimal conditions for the metabolism and growth of the organism as a whole. On the other hand, the administration of nettle extract to control and stressed animals promotes activation of its own antioxidant system, which is important for enhancing the resistance and adaptive capacity of the organism in a critical situation.

\section{Conclusion}

The administration of nettle extract in the norm, and especially under the influence of stress, stimulates erythropoiesis and hemoglobin synthesis, normalizes protein metabolism, inhibits free radical processes and increases endogenous antioxidant defense reserves in blood and tissues of rats. The positive effect of nettle watering to stress-exposed animals is the normalization of homeostasis and increasing adaptive mechanisms in the whole body. Administration of $40 \%$ nettle extract to rats led to the suppression of the formation of active forms of oxygen, reduction of their subsequent pathogenic effects and stimulated its own antioxidant defense system in the body. Therefore, our results give an opportunity to argue for the use of nettle (Urtica dioica L.) in the prophylaxis and treatment of stress states. 


\section{References}

Abuajah, C. I., Ogbonna, A. C., \& Osuji, C. M. (2015). Functional components and medicinal properties of food: A review. Journal of Food Science and Technology, 52(5), 2522-2529.

Ahmed, A. A., Zain, U., Abjuluziz, M. A., Rius, U., Iubul, H., \& Muhammad, T. (2012). Evaluation of the chemical composition and element analysis of Urtica dioica. African Journal of Pharmacy and Pharmacology, 21, 1555-1558.

Ahn, K. (2017). The worldwide trend of using botanical drugs and strategies for developing global drugs. Biochemistry and Molecular Biology Reports, 50(3), 111-116.

Birben, E., Sahiner, U. M., Sackesen, C., Erzurum, S., \& Kalayci, O. (2012). Oxidative stress and antioxidant defense. World Allergy Organization Journal, 5(1), 9-19.

Buchko, O., Iaremkevych, O., \& Konechna, R. (2016). Antyoksydantna aktyvnist' kropyvy dvodomnoi' (Urtica dioica L.) [Antioxidant activity of nettle (Urtica dioica L.)]. Visnyk of the Lviv University, Biology, 73, 3-7 (in Ukrainian).

Cai, Z., \& Yan, L. J. (2013). Protein oxidative modifications: Beneficial roles in disease and health. Journal of Biochemical and Pharmacological Research, $1(1), 15-26$.

Carr, A. C., \& Lykkesfeldt, J. (Eds.). (2017). Vitamin C in health and disease. Nutrients, MDPI

Chendey, T. V., Rishko, M. V., \& Boyko, N. V. (2013). Vplyv spozhyvannja kropyvy na endotelial'nu funkciju ta markery sercevo-sudynnogo ryzyku v grupah vysokogo ryzyku: Randomizovane kontrol'ovane doslidzhennja [Effects of consumption of nettle on endothelial function and cardiovascular risk markers in at-risk groups: A randomized controlled trial]. Scientific Bulletin of the Uzhgorod University, Medicine, 46, 51-56 (in Ukrainian).

Choi, D. Y., Lee, Y. J., \& Hong, J. T. (2012). Antioxidant properties of natural polyphenols and their therapeutic potentials for Alzheimer's disease. Brain Research Bulletin, 87(2-3), 144-153.

De Vico, G., Guida, V., \& Carella, F. (2018). Urtica dioica (Stinging nettle): A neglected plant with emerging growth promoter/immunostimulant properties for farmed fish. Frontiers in Physiology, 285, 1-5.

Gaballu, F. A., Gaballu, Y. A., Khyavy, O. M., Mardomi, A., Ghahremanzadeh, K. Shokouhi, B., \& Mamandy, H. (2015). Effects of a triplex mixture of Peganum harmala, Rhus coriaria, and Urtica dioica aqueous extracts on metabolic and histological parameters in diabetic rats. Pharmaceutical Biology, 53(8), 1104-1109.

Ghasemi, S., Moradzadeh, M., Hosseini, M., Beheshti, F., \& Sadeghnia, H. R. (2018). Beneficial effects of Urtica dioica on scopolamine-induced memory impairment in rats: Protection against acetylcholinesterase activity and neuronal oxidative damage. Drug and Chemical Toxicology, 10, 1-9.

Gorovaya, N. Y., Plaksen, N. V., \& Ustinova, L. V. (2015). Podtverzhdenie effektivnosti i bezopasnosti zhidkogo ekstrakta iz list'ev eleuterokokka [Proof of the efficacy and safety of the liquid extract from the leaves of Eleutherococcus]. Pacific Medical Journal, 2, 66-68 (in Russian).

Güler, E. R. (2013). Investigation of chemopreventive properties of Urtica dioica L., in MCF-7 and MDA 231 breast cancer cell lines. The New England Journal of Medicine, 30, 50-53.

Gupta, R. K., Patel, A. K., \& Kumar, R. (2012). Interactions between oxidative stress, lipid profile and antioxidants in breast cancer: A case control study. Asian Pacific Journal of Cancer Prevention, 13(12), 6295-6298.

Gupta, R. K., Patel, A. K., Shah, N., Choudhary, K. A., Jha, U. K., Yadav, U. C. Gupta, P. K., \& Pakuwal, U. (2014). Oxidative stress and antioxidants in disease and cancer: A review. Asian Pacific Journal of Cancer Prevention, 15(11), 4405-4409.

Hea, L., Hea, T., Farrarb, S., Ji, L., Liua, T., \& Ma, X. (2017). Antioxidants maintain cellular redox homeostasis by elimination of reactive oxygen species. Cellular Physiology and Biochemistry, 44, 532-553.

Jakubczyk, K., Janda, K., Szkyrpan, S., Gutowska, I., \& Wolska, J. (2015). Stinging nettle (Urtica dioica L.) - botanical characteristics, biochemical composition and health benefits. Pomeranian Journal of Life Sciences, 61(2), 191-198

Johnson, T. A., Sohn, J., Inman, W. D., Bjeldanes, L. F., \& Rayburn, K. (2013). Lipophilic stinging nettle extracts possess potent antiinflammatory activity, are not cytotoxic and may be superior to traditional tinctures for treating inflammatory disorders. Phytomedicine, 20(2), 143-147.

Joshi, B. C., Mukhija, M., \& Kalia, A. N. (2014). Pharmacognostical review of Urtica dioica L. International Journal of Green Pharmacy, 8(4), 201-209.

Joshi, B. C., Prakash, A., \& Kalia, A. N. (2015). Hepatoprotective potential of antioxidant potent fraction from Urtica dioica Linn. (whole plant) in $\mathrm{CCl}_{4}$ challenged rats. Toxicology Reports, 2, 1101-1110.

Juma, K. K., Maina, S. G., Muriithi, J. N., Mwangi, B. M., Mworia, J. K., Mwonjoria, M. J., Ngeranwa, J. J. N., \& Mburu, D. N. (2015). Protective effects of Urtica dioica and cimetidine on liver function following acetaminophen induced hepatotoxicity in mice. Journal of Developing Drugs, 4(2), 1-7.

Kaledaite, R., \& Bernatoniene, J. (2011). Investigation of antiradical activity of Salvia officinalis L., Urtica dioica L., and Thymus vulgaris L. extracts as po- tential candidates for a complex therapeutic preparation. Journal of Medicinal Plants Research, 5(25), 6090-6096.

Kandis, H., Karapolat, S., Yildirim, U., Saritas, A., Gezer, S., \& Memisogullari, R. (2010). Effects of Urtica dioica on hepatic ischemia-reperfusion injury in rats. Clinics (Sao Paulo), 65(12), 1357-1361.

Khariv, M. (2016). Dynamika aktyvnosti aminotransferaz syrovatky krovi shhuriv za oksydacijnogo stresu ta dii' liposomal'nogo preparatu [Dynamics of indices of aminotransferase activity in the blood serum of rats under conditions of oxidative stress and effect of liposomal medicinal product]. Visnyk of Dnipropetrovsk University, Biology, Medicine, 7(1), 3-7 (in Ukrainian).

Khavrona, O. (2015). Porushennja funkcionuvannja glutationovoi' lanky antyoksydantnogo zahystu v slyzovij obolonci shlunka, pechinci ta erytrocytah shhuriv pry eksperymental'nij vyrazkovij hvorobi [Disturbances of function of the glutathione antioxidant system in gastric mucosa, liver and erythrocytes of rats with experimental gastric lesions]. Experimental and Clinical Physiology and Biochemistry, 69(1), 26-31 (in Ukrainian).

Kopyt'ko, Y. F., Lapinskaya, E. S., \& Sokol'skaya, T. A. (2011). Primenenie, himicheskij sostav i standartizacija syrja i preparatov Urtica (Obzor) [Application, chemical composition, and standardization of nettle raw material and related drugs]. Chemical-Pharmaceutical Journal, 45(10), 32-41 (in Russian).

Lindblad, M., Tveden-Nyborg, P., \& Lykkesfeldt, J. (2013). Regulation of vitamin C homeostasis during deficiency. Nutrients, 5(8), 2860-2879.

Mirtaghi, S. M., Torbati Nejad, P. T., Mazandarani, M., Livani, F., \& Bagheri, H. (2016). Evaluation of antibacterial activity of Urtica dioica L. leaf ethanolic extract using agar well diffusion and disc diffusion methods. Medical Laboratory Journal, 10(5), 15-21.

Mizutani, T., \& Masaki, H. (2014). Anti-photoaging capability of antioxidant extract from Camellia japonica leaf. Experimental Dermatology, 23(1), 23-26.

Molyneux, P. (2004). The use of the stable free radical diphenylpicrylhydrazyl (DPPH) for estimating antioxidant activity. Songklanakarin Journal of Science and Technology, 26(2), 211-219.

Namazi, F., Shomali, T., Taghikhani, P., \& Nazifi, S. (2018). Protective effect of Urtica dioica leaf hydro alcoholic extract against experimentally-induced atherosclerosis in rats. Avicenna Journal of Phytomedicine, 8(3), 254-262.

Oltjen, J. W., Kebreab, E., \& Lapierre, H. (2013). Energy and protein metabolism and nutrition in sustainable animal production. EAAP Scientific Series, 134.

Paidi, M. D., Schjoldager, J. G., Lykkesfeldt, J., \& Tveden-Nyborg, P. (2014). Prenatal vitamin $\mathrm{C}$ deficiency results in differential levels of oxidative stress during late gestation in foetal guinea pig brains. Redox Biology, 2, 361-367.

Qaid, A. (2016). Role of insulin and other related hormones in energy metabolism A review. Cogent Food and Agriculture, 2, 1-18.

Rabasa, C., \& Dickson, S. L. (2016). Impact of stress on metabolism and energy balance. Current Opinion in Behavioral Sciences, 9, 71-77.

Rutto, L. K., Xu, Y., Ramirez, E., \& Brandt, M. (2013). Mineral properties and dietary value of raw and processed stinging nettle (Urtica dioica L.). International Journal of Food Science, 2013, 1-9.

Salih, N. A. (2015). Effect of nettle (Urtica dioica) extract on gentamicin induced nephrotoxicity in male rabbits. Asian Pacific Journal of Tropical Biomedicine, 5(9), 756-760

Seliya, M., \& Kothiyal, P. (2014). Urtica dioica (stinging nettle): A review of its chemical, pharmacological, toxicological and ethnomedical properties. International Journal of Pharmacy, 4(1), 270-277.

Shkurashivska, S. V., \& Erstenyuk, H. M. (2015). Dynamika zmin pokaznykiv lipidnogo obminu v organah i tkanynah eksperymental'nyh tvaryn za umov adrenalinovogo stresu [Dynamics of changes in lipid metabolism indices in organs and tissues of experimental animals under adrenaline stress]. Medical and Clinical Chemistry, 17(4), 34-37 (in Ukrainian).

Spatafora, C., \& Tringali, C. (2012). Natural-derived polyphenols as potential anticancer agents. Anti-Cancer Agents in Medicinal Chemistry, 12(8), 902-918.

Teloa, S., Halifeoglub, I., \& Ozercan, I. H. (2017). Effects of stinging nettle (Urtica dioica $\mathrm{L}$.) on antioxidant enzyme activities in rat model of mammary gland cancer. Iranian Journal of Pharmaceutical Research, 16, 164-170.

Vlizlo, V. V. (Ed.). (2012). Laboratorni metody doslidzhen u biolohii, tvarynnytstvi ta veterynamii medytsyni [Laboratory methods of investigation in biology, stock-breeding and veterinary]. Spolom, Lviv (in Ukrainian).

Wolska, J., Janda, K., Szkyrpan, S., \& Gutowska, I. (2015). The influence of stinging nettle (Urtica dioica L.) extracts on the activity of catalase in THP1 monocytes/macrophages. Pomeranian Journal of Life Sciences, 61(3), 315-318.

Woo, Y., Lee, H., Jeong, Y.-S., Shin, G. Y., Oh, J. G., Kim, J.-S., \& Oh, J. (2017) Antioxidant potential of selected Korean edible plant extracts. BioMed Research International, 17, 1-9.

Yakimova, T. V., Nasanova, O. N., \& Vengerovsky, A. I. (2015). Vlijanie ekstraktov lekarstvennyh rastenij na metabolicheskie narushenija pri modeli saharnogo diabeta i insulinorezistentnosti [Influence of herbal extracts on metabolic disturbances in diabetes mellitus and insulin resistance model]. Bulletin of Siberian Medicine, 14(2), 75-81 (in Russian). 
Yang, E. J., Lee, J.-S., Song, B. B., Yun, C.-Y., Kim, D.-H., \& Kim, I. S. (2011) Anti-inflammatory effects of ethanolic extract from Lagerstroemia indica on airway inflammation in mice. Journal of Ethnopharmacology, 136(3), 422-427.

Zagayko, A. L., Krasilnikova, O. A., Kravchenko, G. B., \& Kochubey, Y. I. (2017) Vyvchennja gepatoprotektornoi' aktyvnosti roslynnyh polifenoliv na modeli eksperymental'noi' insulinorezystentnosti [Hepatoprotective activity study of plant polyphenols under the experimental insulin resistance]. World of Medicine and Biology, 59, 117-121 (in Ukrainian).
Zemmouri, H., Sekioua, O., Ammar, S., Feki, A. E., Bouaziz, M., Messaraha, M. \& Boumendjel, A. (2017). Urtica dioica attenuates ovalbumin-induced inflammation and lipid peroxidation of lung tissues in rat asthma model. Pharmaceutical Biology, 55(1), 1561-1568.

Zhang, Y.-J., Gan, R.-Y., \& Lietal, S. (2015). Antioxidant phytochemicals for the prevention and treatment of chronic diseases. Molecules, 20(12), 21138-21156. 